\title{
Lack of association between an interleukin-1 receptor antagonist gene polymorphism and ulcerative colitis
}

\author{
U T Hacker, M Gomolka, E Keller, A Eigler, C Folwaczny, H Fricke, E Albert, \\ K Loeschke, S Endres
}

\begin{abstract}
Background-Recently, the association of a polymorphism in the gene coding for the anti-inflammatory cytokine interleukin-1 receptor antagonist with ulcerative colitis has been reported. This was interpreted as a possible genetic predisposition for severity of the inflammatory response. Aims-To examine this polymorphism in a southern German population.

Subjects-The study included 234 healthy controls, 57 patients with ulcerative colitis, including 31 patients with pancolitis, 44 first degree healthy relatives of patients with ulcerative colitis, and 65 patients with Crohn's disease.

Methods-Genotypes were determined by a polymerase chain reaction amplification of the intron 2 fragment harbouring a variable number of tandem repeat nucleotide sequences. Amplification products were separated on a $2 \%$ agarose gel. Results-The allele frequency for allele 2 was $27 \%$ in healthy controls, $28 \%$ in Crohn's disease, and $21 \%$ in patients with ulcerative colitis. The same allele frequency $(21 \%)$ was found in a subgroup of patients with ulcerative colitis affecting the whole colon. Thus for allele 2 as well as for all other alleles, genotypes, or carriage rates no significant differences were found compared with controls. All allele frequencies in the control population were similar to those in earlier studies. carler study reporting an increased quency of allele 2 , particularly in patients with pancolitis, could not be confirmed. (Gut 1997; 40: 623-627)
\end{abstract}

Medizinische Klinik, Klinikum Innenstadt U T Hacker A Eigler

C Folwaczny

H Fricke

K Loeschke

$S$ Endres

Laboratory for Immungenetics, Kinderpoliklinik,

Klinikum Innenstadt of the Ludwig-MaximiliansUniversity Munich,

Germany

E Albert

M Gomolka

E Keller

Correspondence to: Dr Stefan Endres, Medizinische Klinik, Klinikum Innenstadt Klinikum Innens derUniversität, Ziemssenstraße 1 , 80336 München.

Accepted for publication 23 December 1996

Keywords: cytokine, interleukin-1 receptor antagonist, polymorphism, inflammatory bowel disease, ulcerative colitis, genetics.

Clear evidence exists for a genetic predisposition to inflammatory bowel disease. The prevalence of ulcerative colitis and Crohn's disease is different between distinct ethnic groups. ${ }^{1}$ Relatives of patients with ulcerative colitis and Crohn's disease have an increased risk for developing inflammatory bowel disease. ${ }^{2-5}$ Furthermore, twin studies have provided evidence for genetic factors, particularly in Crohn's disease. ${ }^{6}$ Genetic markers for inflammatory bowel disease have been identified in the major histocompatibility complex. ${ }^{7}$ An association between the HLA-DR2 allele and ulcerative colitis has been described. ${ }^{8}$ In Crohn's disease the haplotype HLA-DR1 $\mathrm{DQ}_{\mathrm{w} 5}$ was found with increased frequency. ${ }^{8}$

Interleukin-1 is a cytokine with potent proinflammatory properties and plays a central part in various inflammatory diseases. ${ }^{9-11}$ It is the only cytokine for which a physiological antagonist - interleukin-1 receptor antagonist - has been identified. ${ }^{12-17}$ The results of a study by Casini et al point to a role for the balance between the proinflammatory cytokine interleukin-1 and its receptor antagonist in inflammatory bowel disease. ${ }^{18}$

A polymorphism in the gene coding for interleukin-1 receptor antagonist has been described $^{19}$ (Table I). In the second intron of this gene five alleles are defined by different numbers (two to six) of repeats of a $86 \mathrm{bp}$ segment (variable number of tandem repeats). Recently, an association between this polymorphism and ulcerative colitis has been described. ${ }^{20}$ An increase in the frequency of allele 2 was reported in patients with ulcerative colitis, especially in those with involvement of the entire colon. This was the first observed association of ulcerative colitis with a gene outside the major histocompatibility complex. There are interindividually stable differences in the production of certain cytokines. ${ }^{21} 22$ The genotype of the polymorphism in the interleukin-1 receptor antagonist gene may influence its production, as possible binding sites for transcription factors have been characterised in this region. ${ }^{19}$ Recently, an influence of the allele status on the production of interleukin-1
TABLE I Polymorphism of the interleukin-1 receptor antagonist gene

\begin{tabular}{lll}
\hline Name of allele & $\begin{array}{l}\text { Number of } \\
\text { repeats }(R)\end{array}$ & $\begin{array}{l}\text { PCR product: } \\
\text { number of } \\
\text { base pairs }\end{array}$ \\
\hline A1 & RRRR (4) & 410 \\
A2 & RR(2) & 240 \\
A3 & RRRRR (5) & 500 \\
A4 & RRR (3) & 325 \\
A5 & RRRRRR (6) & 595 \\
\hline
\end{tabular}

Five alleles can be distinguished in intron 2 of the interleukin- 1 receptor antagonist gene polymorphism. The table shows the nomenclature, the number of repeats found in these alleles, and the size of the products by PCR amplification. 
receptor antagonist was noted. Allele 2 of the polymorphism was associated with an increased production of interleukin-1 receptor antagonist protein in healthy humans when mononuclear cells were stimulated with GM-CSF. ${ }^{23}$ It was speculated that a genetic influence - caused by the polymorphism in the interleukin-1 receptor antagonist gene - on the production of interleukin-1 receptor antagonist could contribute to the mechanism of inflammatory disease. In the present study we attempted to confirm the recently described ${ }^{20}$ association of the polymorphism in the interleukin-1 receptor antagonist gene in a large southern German patient population with ulcerative colitis.

\section{Methods}

PATIENTS

The study comprised 234 unrelated healthy volunteers, 57 patients with ulcerative colitis, and 65 patients with Crohn's disease. Furthermore, 44 first degree relatives of patients with ulcerative colitis were studied. The diagnosis and extent of disease had been determined by radiological, endoscopic, and histological criteria (Table II). Informed consent was obtained from all patients.

TABLE II Patient characteristics

\begin{tabular}{lll}
\hline & $\begin{array}{l}\text { Ulcerative } \\
\text { colitis }\end{array}$ & $\begin{array}{l}\text { Crohn's } \\
\text { disease }\end{array}$ \\
\hline Total number (n) & 57 & 65 \\
Sex F/M (n) & $31 / 26$ & $47 / 18$ \\
Age (years): & & \\
(mean (SD)) & $39 \cdot 9(11 \cdot 9)$ & $35 \cdot 1(10 \cdot 5)$ \\
(median/range) & $40 / 17-66$ & $33 / 19-69$ \\
Age at onset of symptoms: & & \\
(mean (SD)) & $31 \cdot 0(11 \cdot 8)$ & $23 \cdot 7(6 \cdot 9)$ \\
(median) & 29 & 22 \\
Duration of symptoms: & & \\
(mean (SD)) & $9 \cdot 2(6 \cdot 3)$ & $11 \cdot 5(7 \cdot 9)$ \\
(median) & 8 & 9 \\
Site of disease: & & \\
Small bowel involved & 0 & 53 \\
$\quad$ Terminal ileum & 0 & 48 \\
Other small bowel & 0 & 5 \\
Colon involved & 57 & 55 \\
$\quad$ Right colon & 0 & 20 \\
Left colon & 8 & 19 \\
$\quad$ Distal colon & 16 & 3 \\
$\quad$ Rectum & 2 & 9 \\
Total colon & 31 & \\
\hline
\end{tabular}

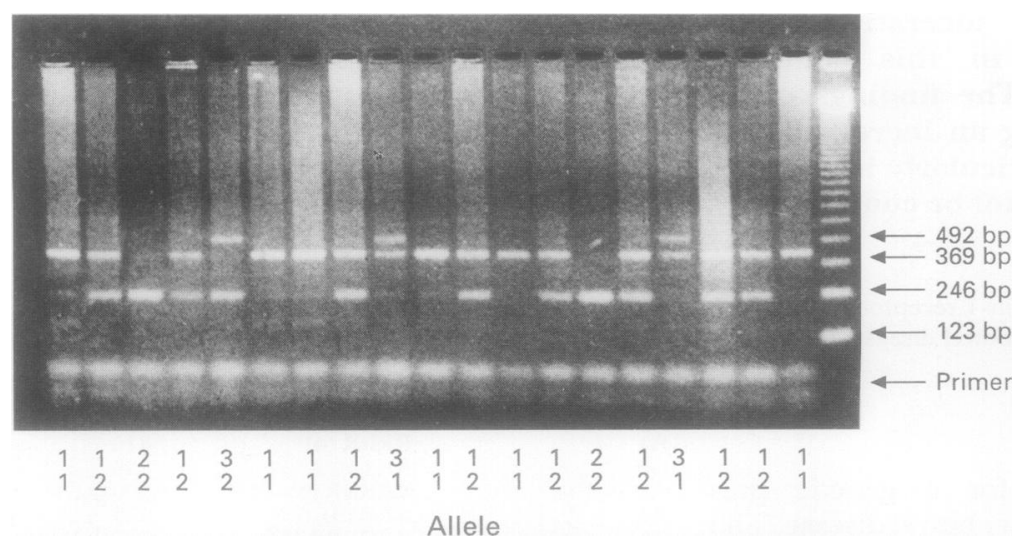

Figure 1: Agarose gel (2\%) stained with ethidium bromide. PCR products ( $8 \mu \mathrm{l}$ ) of 19 unrelated, healthy controls were separated by electrophoresis. The marker ladder ranges from 123 to 4182 base pairs (bp) in steps of $123 \mathrm{bp}$. In the samples fragments of $240 \mathrm{bp}, 410 \mathrm{bp}$, and 500 bp can be identified, which represent alleles 2, 1, and 3 respectively. The deduced genotypes are indicated below each lane.
ISOLATION OF DNA

Genomic DNA was extracted from $10 \mathrm{ml}$ peripheral blood collected into tubes containing ethylenediaminetetra-acetic acid (EDTA), using a salting out procedure described elsewhere. ${ }^{24}$ The DNA samples of the patient groups in this study have not been previously investigated.

POLYMERASE CHAIN REACTION

The polymerase chain reaction (PCR) was used to identify the genotypic status of the polymorphism in intron 2 of the interleukin-1 receptor antagonist gene..$^{25}$ Negative controls were included within each of the reactions. Approximately $250 \mathrm{ng}$ DNA was subjected to PCR amplification of the $86 \mathrm{bp}$ tandem repeat polymorphism in a GeneAmp PCR System 9600 (Perkin Elmer, Weiterstadt, Germany). Primers as described by Tarlow et al ${ }^{19}$ (5'CTCAGCAACACTCCTAT3' and 5'TCCTGGTCTGCAGGTAA3' (Pharmacia Biotech Europe GmbH, Freiburg, Germany)) were used at a final concentration of $1 \mu M$ each. PCR Buffer II 10× (Perkin Elmer, Weiterstadt, Germany) contained $100 \mathrm{mM}$ Tris- $\mathrm{HCl}$ at $\mathrm{pH}$ $8 \cdot 3\left(25^{\circ} \mathrm{C}\right)$ and $500 \mathrm{mM} \mathrm{KCl}$. The final $\mathrm{MgCl}_{2}$ concentration in the PCR reaction was $3 \mathrm{mM}$. Dimethyl sulphoxide (DMSO; 2\%; Sigma, Munich, Germany) was added. The reaction volume was $20 \mu \mathrm{l}$. The incubation parameters were: first denaturation at $94^{\circ} \mathrm{C}$ for three minutes followed by $94^{\circ} \mathrm{C}$ (one minute), $65^{\circ} \mathrm{C}$ (one minute), and $72^{\circ} \mathrm{C}$ (one minute) for two cycles, $94^{\circ} \mathrm{C}$ (one minute), $63^{\circ} \mathrm{C}$ (one minute), and $72^{\circ} \mathrm{C}$ (one minute) for two cycles and $94^{\circ} \mathrm{C}$ (one minute), $60^{\circ} \mathrm{C}$ (one minute), and $72^{\circ} \mathrm{C}$ (one minute) for 30 cycles. The final extension was carried out at $72^{\circ} \mathrm{C}$ for five minutes. The PCR product was separated by electrophoresis on a $2 \%$ agarose gel stained with ethidium bromide. A molecular ladder in steps of $123 \mathrm{bp}$ ranging from 123 to $4182 \mathrm{bp}$ (Gibco BRL, Berlin, Germany) was used to determine the size of the PCR products (Fig 1).

STATISTICS

The allele frequencies and carriage rates were calculated from the numbers of genotypes. For statistical analyses the $\chi^{2}$ test was performed on allele frequencies, and genotypes and carriage rates.

\section{Results}

In healthy controls $(n=234)$ allele frequencies were $69 \%$ for allele $1,27 \%$ for allele 2 , and $4 \%$ for the sum of alleles 3, 4, and 5 (Table III). In patients with ulcerative colitis the frequency of allele 2 was decreased compared with the controls $(21 \% v 27 \%)$ as was the carriage rate of allele $2(39 \% v 49 \%)$. The frequency of allele 1 was increased (77\% v 69\%) compared with controls (Fig 2). Subdividing the patients with ulcerative colitis by extent of disease, the frequency of allele 2 was $22 \%$ in disease affecting the distal colon, $19 \%$ in disease affecting the left hemicolon, and $21 \%$ in 
TABLE II Genotype numbers in patients and controls (total numbers) and calculated allele frequencies $(\%)$

\begin{tabular}{|c|c|c|c|c|c|c|c|c|c|c|}
\hline & \multicolumn{7}{|c|}{ Genotypes (n) } & \multicolumn{3}{|c|}{ Alleles $\left({ }^{\circ} \mathrm{o}\right)$} \\
\hline & 1,1 & 1,2 & 2,2 & 1,3 & 2,3 & 1,5 & 1,4 & 1 & 2 & $\begin{array}{l}3,4 \\
\text { or } 5\end{array}$ \\
\hline $\begin{array}{l}\text { Healthy controls } \\
(n=234) \\
\text { Crohn's disease }\end{array}$ & 107 & 97 & 13 & 10 & 4 & 2 & 1 & 69 & 27 & 4 \\
\hline $\begin{array}{l}\quad(n=65) \\
\text { Ulcerative colitis }\end{array}$ & 35 & 24 & 6 & 0 & 0 & 0 & 0 & 72 & 28 & 0 \\
\hline $\begin{array}{l}\quad(n=57) \\
\text { Relatives of patients }\end{array}$ & 33 & 20 & 2 & 2 & 0 & 0 & 0 & 77 & 21 & 2 \\
\hline $\begin{array}{l}\text { With ulcerative } \\
\text { colitis }(n=4 \cdot 4)\end{array}$ & 21 & 16 & 6 & 1 & 0 & 0 & 0 & 67 & 32 & 1 \\
\hline
\end{tabular}

patients with an involvement of the entire colon (Fig 3). The allele frequencies, genotype frequencies, and carriage rates showed no significant differences in these subgroups of patients with ulcerative colitis compared with controls. Also in the first degree healthy relatives of patients with ulcerative colitis, allele and genotype frequencies were similar to controls (Table III).

In patients with Crohn's disease the allele frequencies were $72 \%$ for allele 1 and $28 \%$ for allele 2 (Table III). A carriage rate for allele 2 of $46 \%$ compared with $49 \%$ in controls was calculated. Using the $\chi^{2}$ test no significant differences in genotype frequencies, allele frequencies, or carriage rates could be found in patients with Crohn's disease compared with

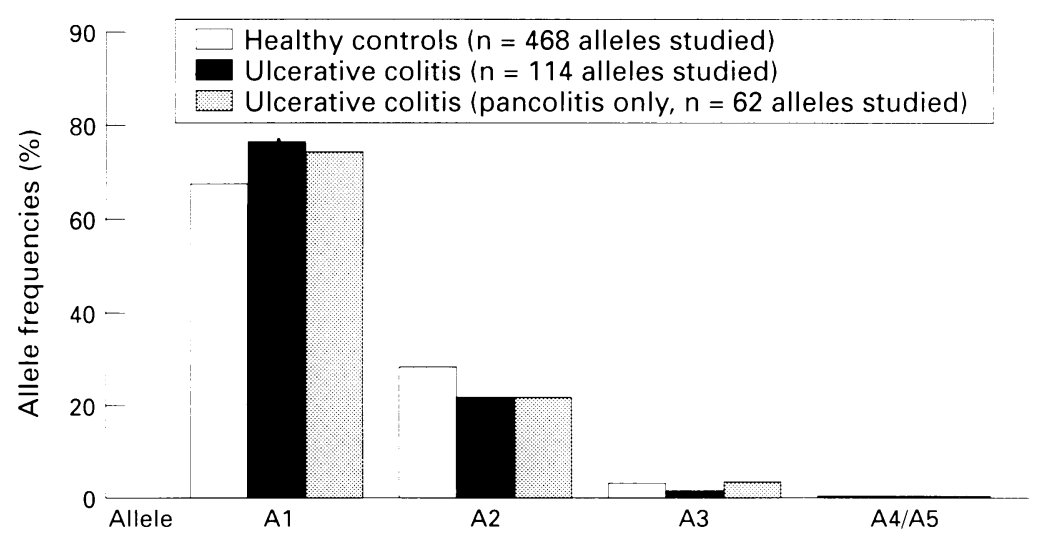

Figure 2: Allele frequencies of the interleukin-1 receptor antagonist polymorphism in patients with ulcerative colitis and in the subgroup with pancolitis in comparison with healthy. controls.

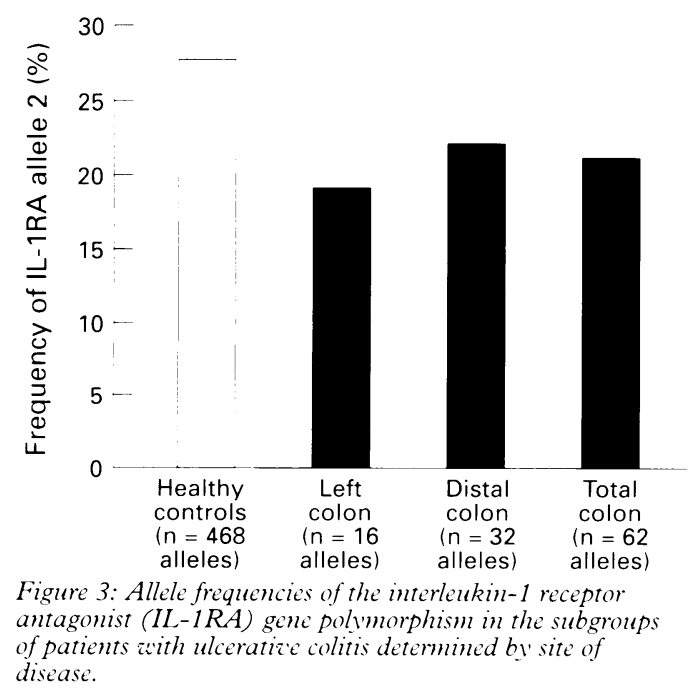

healthy controls. This was in accordance with previous findings. ${ }^{20}$

Thus in this study no significant association between a polymorphism in the interleukin-1 receptor antagonist gene and either ulcerative colitis or Crohn's disease could be identified. In particular we found no increase in the frequency of allele 2 in the subgroup of 31 patients with pancolitis, compared with the 20 patients in the study by Mansfield et al..$^{20}$ The genotype frequencies of all groups (healthy controls, patients with Crohn's disease, patients with ulcerative colitis, and first degree healthy relatives of patients with ulcerative colitis) were consistent with Hardy-Weinberg equilibrium.

\section{Discussion}

The present study found a decreased allele frequency and carriage rate of allele 2 of the interleukin-1 receptor antagonist polymorphism in 57 patients with ulcerative colitis compared with 234 healthy controls. This corresponded with an increased allele frequency and carriage rate of allele 1 in this patient group. The differences determined, however, did not reach significance. In the control group, genotype and allele frequencies were similar to those described in other healthy controls. ${ }^{19} 20$ In 65 patients with Crohn's disease allele frequencies were almost equal to those in the healthy control group.

In the study of Mansfield et al the uncommon allele 2 of this polymorphism in the interleukin-1 receptor antagonist gene was more frequent in patients with ulcerative colitis than in healthy controls. ${ }^{20}$ This increase could be attributed entirely to the subgroup of 20 patients with pancolitis, in which the frequency of allele 2 was $52 \cdot 5 \%$.

Our present results confirm the findings of Mansfield et al, ${ }^{20}$ firstly, for healthy controls and, secondly, for patients with Crohn's disease, in whom no correlation with any allele of this interleukin-1 receptor antagonist polymorphism was found. By contrast, our results were different for patients with ulcerative colitis. In particular, in the subgroup with ulcerative colitis affecting the whole colon, we found an allele 2 frequency of $21 \%$, which was not different from that in all patients with ulcerative colitis $(21 \%)$ and was decreased (non-significantly) compared with healthy controls $(27 \%)$. Methodical reasons are unlikely to be responsible for the differences, because the results found in the healthy controls were similar in both studies. These findings raise the question whether the association may only be found in distinct ethnic groups and may be absent in others. It has been shown recently that the association of allele 2 of the interleukin- 1 receptor antagonist polymorphism with ulcerative colitis was only detectable in a Jewish subgroup of a patient population in Los Angeles, but not in the whole study cohort. ${ }^{26}$ Furthermore, in preliminary reports, the allele 2 frequency was not different from control groups in a Spanish and a Dutch population of patients with ulcerative 
colitis. ${ }^{27}$ In view of the data, it seems unlikely that an association of the intron 2 interleukin-1 receptor antogonist polymorphism with ulcerative colitis exists in the general population of patients with this disease.

Both in peripheral blood and in mucosal biopsy samples of patients with inflammatory bowel disease increased amounts of interleukin-1 and interleukin-1 receptor antagonist have been measured. ${ }^{28-31}$ In a study by Casini et al the ratio of interleukin-1 receptor antagonist versus interleukin-1 was decreased in the mucosa of both ulcerative colitis and Crohn's disease but not in self limiting colitis. ${ }^{18}$ It was hypothesised that defective interleukin-1 receptor antagonist production could explain disease reactivation and chronicity. ${ }^{32}$ In animal models neutralisation of endogenous interleukin-1 receptor antagonist with specific antibodies led to exacerbation and prolongation of inflammation. ${ }^{33}$ Furthermore, recombinant interleukin-1 receptor antagonist has been successfully applied in animal models of inflammatory bowel disease. ${ }^{34} 35$

The influence of the polymorphism investigated here on production of interleukin-1 receptor antagonist protein has recently been studied. ${ }^{23}$ After stimulation with GM-CSF, mononuclear cells from healthy persons carrying allele 2 in one or two copies produced more interleukin- 1 receptor antagonist and less proinflammatory interleukin-1 $\alpha$ compared with those carrying one or no copies of allele $2 .{ }^{23}$ From these data it would not be expected that carriage of allele 2 would confer increased susceptibility to an inflammatory response. By contrast, a recent presentation described decreased levels of interleukin-1 receptor antagonist in inflamed bowel mucosa of carriers of allele 2 compared with non-carriers of this allele. ${ }^{36}$ Together, the published data on the influence of this polymorphism on production of interleukin-1 receptor antagonist protein are not yet conclusive.

In summary, we found no association between ulcerative colitis and the intron 2 polymorphism in the gene coding for the interleukin-1 receptor antagonist in a southern German group of patients. It seems unlikely that allele 2 of this polymorphism represents a marker for ulcerative colitis in the general population.

We thank Dr Gunther Hartmann, Dr Jochen Moeller, Désirée Zarskyi, Uta Emmerich, Anne Krug, and Britta Siegmund, for most helpful discussions. The experimental data of this study are part of the dissertation of $C$ Bidlingmaier (Medizinische Fakultät der Ludwig-Maximilians-Universität München, in preparation). The work was supported by grant En $169-2 / 3$.
SFB 217 from the Deutsche Forschungsgemeinschaft.

1 Satsangi J, Jewell DP, Rosenberg WM, Bell JI. Genetics of inflammatory bowel disease. Gut 1994; 35: 696-700.

2 Farmer RG, Michener WM, Mortimer EA. Studies of family history among patients with infla

disease. Clin Gastroenterol 1980; 9: 271-7.

Yang H, McElree C, Roth MP, Shanahan F, Targan SR, Rotter JI. Familial empirical risks for inflammatory bowel disease: differences between Jews and non-Jews. Gut 1993; 34: 517-24.

4 Yang H, Rotter JI, Toyoda H, Landers C, Tyran D, McElree $\mathrm{CK}$, et al. Ulcerative colitis: a genetically heterogeneous disorder defined by genetic (HLA class II) and subclinical (antineutrophil cytoplasmic antibodies) markers. $\mathcal{f}$ Clin Invest 1993; 92: 1080-4.
5 Roth MP, Petersen GM, McElree C, Vadheim CM, Panish JF, Rotter JI. Familial empiric risk estimates of inflammatory bowel disease in Ashkenazi Jews. Gastroenterology 1989; 96: 1016-20.

6 Tysk C, Lindberg E, Jarnerot G, Floderus MB. Ulcerative colitis and Crohn's disease in an unselected population of monozygotic and dizygotic twins. A study of heritability and the influence of smoking. Gut 1988; 29: 990-6.

7 Satsangi J, Welsh KI, Bunce M, Julier C, Farrant JM, Bell JI, et al. Contribution of genes of the mayor histocompatibility complex and disease phenotype in inflammatory bowel disease. Lancet 1996; 347: 1212-7.

8 Toyoda H, Wang SJ, Yang HY, Redford A, Magalong D, Tyan D, et al. Distinct associations of HLA class II gene with inflammatory bowel disease. Gastroenterology 1993 104: 741-8.

9 Dinarello CA. Biologic basis for interleukin-1 in disease. Blood 1996; 87: 2095-147.

10 Dinarello CA. The interleukin-1 family: 10 years of discovery. FASEB F 1994; 8: 1314-25.

11 Dinarello CA. Interleukin-1 and interleukin-1 antagonism. Blood 1991; 77: 1627-52.

12 Hannum CH, Wilcox CJ, Arend WP, Joslin FG, Dripps DJ, Heimdal PL, et al. Interleukin-1 receptor antagonis activity of a human interleukin-1 inhibitor. Nature 1990 343: 336-40

13 Carter DB, Deibel MJ, Dunn CJ, Tomich CS, Laborde AL Slightom JL, et al. Purification, cloning, expression and biological characterization of an interleukin-1 recepto antagonist protein. Nature 1990; 344: 633-8.

14 Dinarello CA, Thompson RC. Blocking IL-1: interleukin 1 receptor antagonist in vivo and in vitro. Immunol Today 1991; 12: 404-10.

15 Eisenberg SP, Evans RJ, Arend WP, Verderber E, Brewer $\mathrm{MT}$, Hannum CH, et al. Primary structure and functional expression from complementary DNA of a human expression from complementary DNA of a human interleukir.

16 Arend WP. Interleukin 1 receptor antagonist. A new member of the interleukin 1 family. $\mathcal{F}$ Clin Invest 1991 ; 88: $1445-51$.

17 Eisenberg SP, Brewer MT, Verderber E, Heimdal P, Brandhuber BJ, Thompson RC. Interleukin 1 receptor antagonist is a member of the interleukin-1 gene family: evolution of a cytokine control mechanism. Proc Natl Acad Sci USA 1991; 88: 5232-6.

18 Casini RV, Kam L, Chong YJ, Fiocchi C, Pizarro TT, Cominelli F. Mucosal imbalance of IL-1 and IL-1 receptor antagonist in inflammatory bowel disease. A novel mechanism of chronic intestinal inflammation. Immunol 1995; 154: 2434-40.

19 Tarlow JK, Blakemore AI, Lennard A, Solari R, Hughes $\mathrm{HN}$, Steinkasserer A, et al. Polymorphism in human IL-1 receptor antagonist gene intron 2 is caused by variable numbers of an 86-bp tandem repeat. Hum Genet 1993 91: 403-4.

20 Mansfield JC, Holden H, Tarlow JK, Di Giovine FS McDowell TL, Wilson AG, et al. Novel genetic association between ulcerative colitis and the antiinflammatory cytokine interleukin-1 receptor antagonist. Gastroenterology 1994; 106: 637-42.

21 Molvig J, Baek L, Christensen P, Manogue KR, Vlassara H, Platz $\mathrm{P}$, et al. Endotoxin-stimulated human monocyte secretion of interleukin-1, tumor necrosis factor $\alpha$, and prostaglandine $E_{2}$ shows stable interindividual difprostaglandine $\mathrm{E}_{2}$ shows stable interind

22 Endres S, Cannon JG, Ghorbani R, Dempsey RA, Sisson $S D$, Lonnemann G, et al. In vitro production of IL $1 \beta$, IL $1 \alpha$, TNF and IL-2 in healthy subjects: distribution effect of cyclooxygenase inhibition and evidence of independent gene regulation. Eur $\mathcal{F}$ Immunol 1989; 19 2327-33.

23 Danis VA, Millington M, Hyland VJ, Grennan D. Cytokine production by normal human monocytes: inter-subject variation and relationship to an IL-1 receptor antagonist (IL-1Ra) gene polymorphism. Clin Exp Immunol 1995; 99: $303-10$.

24 Miller SA, Dykes DD, Polesky HF. A simple salting out procedure for extracting DNA from human nucleated procedure for extracting DNA from
cells. Nucleic Acids Res 1988; 16: 1215 .

25 Saiki RK, Gelfand DH, Stoffel S, Scharf SJ, Higuchi R, Horn GT, et al. Primer-directed enzymatic amplification of DNA with thermostable DNA polymerase. Science 1988; 239: 487-91

26 Tountas NA, Yang H, Coulter DL, Rotter JI, Cominelli F Increased carriage of allele 2 of IL-1 receptor antagonis (IL-1 ra) in Jewish populations: the strongest known genetic association in ulcerative colitis [abstract] Gastroenterology 1996; 110 (suppl): A1029.

27 Garcia-Paredes J, Bioque G, Crusius JBA, Garcia-Gonzále A, López-Nava M, Diaz-Rubio $M$, et al. The interleukin-1 receptor antagonist gene polymorphism in Spanish IBD patients [abstract]. Gastroenterology 1996; 110 (suppl) A914.

28 Youngman KR, Simon PL, West GA, Cominelli F, Rachmilewitz D, Klein JS, et al. Localization of intestinal interleukin 1 activity and protein and gene expression to interleukin 1 activity and protein and gene expression to

29 Nishinama T, Mitsuyama K, Toyonaga A Sasai E Tanikawa K. Mitsuyama K, Toyonaga A, Sasaki E, antagonist in inflammatory bowel disease. Digestion 1994; 55: $368-73$.

30 Hyams JS, Fitzgerald JE, Wyzga N, Treem WR, Justinich CJ, Kreutzer DL. Characterization of circulating interleukin-1 receptor antagonist expression in children 
with inflammatory bowel disease. Dig Dis Sci 1994; 39: 1893-9.

31 Nakamura M, Saito H, Kasanuki J, Tamura Y, Yoshida S. Cytokine production in patients with inflammatory bowel disease. Gut 1992; 33: 933-7.

32 Isaacs KL, Sartor RB, Haskill S. Cytokine messenger RNA profiles in inflammatory bowel disease mucosa detected by polymerase chain reaction amplification. Gastroenterology 1992; 103: 1587-95.

33 Ferretti M, Casini RV, Pizarro TT, Eisenberg SP, Nast CC, Cominelli F. Neutralization of endogenous IL-1 receptor antagonist exacerbates and prolongs inflammation in rabbit immune colitis. $\mathcal{f}$ Clin Invest 1994; 94: 449-53.
34 Cominelli F, Nast CC, Duchini A, Lee M. Recombinant interleukin-1 receptor antagonist blocks the proinflammatory activity of endogenous interleukin-1 in rabbit immune colitis. Gastroenterology 1992; 103: 65-71.

35 Thompson RC, Dripps DJ, Eisenberg SP. Interleukin-1 receptor antagonist (IL-1 ra) as a probe and as a treatment for IL-1 mediated disease. Int $\mathcal{f}$ Immunopharmacol 1992; 14: $475-80$.

36 Andus $T$, Vogl $D$, Aschenbrenner $M$, Köllinger $M$, Schölmerich $M$, Gross V. IL-1RA genotype 2 is Schölmerich $M$, Gross V. IL-1RA genotype 2 is
associated with reduced IL-1RA in colonic mucosa [abstract]. Gastroenterology 1996; 110 (suppl): A855. 